\title{
ANALISIS KEPUASAN DOSEN DAN MAHASISWA TERHADAP KINERJA PROGRAM STUDI PENDIDIKAN GURU SEKOLAH DASAR UNIVERSITAS PAKUAN
}

\author{
Nurlinda Safitri ${ }^{\left.a^{*}\right)}$, Nedin Badruzzaman ${ }^{a)}$, Elly Sukmanasa ${ }^{a)}$ \\ a) Universitas Pakuan, Bogor, Indonesia \\ ${ }^{*}$ e-mail korespondensi : linda_vivian80@yahoo.com
}

Riwayat Artikel : diterima: 06 Desember 2019; direvisi: 19 Desember 2019; disetujui: 26 Januari 2020

\begin{abstract}
Abstrak. Kualitas lembaga pendidikan sangat dipengaruhi oleh masukan dari berbagai faktor yang mempengaruhinya, diantaranya faktor kebijakan pimpinan, fasilitas sarana pendukung proses belajar mengajar. Kinerja program studi menjadi salah satu tolak ukur sebagian besar dari keberhasilan pendidikan di suatu perguruan tinggi karena akan menentukan terhadap tinggi atau rendahnya kualitas pendidikan di perguruan tinggi. Dosen dan mahasiswa seringkali mengeluhkan tentang kebijakan yang dilaksanakan program studi terutama tentang fasilitas dan sarana di kelas yang kurang baik sehingga proses pembelajaran menjadi kurang kondusif. Dampak dari permasalahan tentang ketidakpuasan pada kinerja program studi ditunjukkan dengan perilaku belajarnya yang tidak nyaman. Tujuan dari penelitian ini untuk mengetahui bagaimana kinerja prodi yang dinilai oleh dosen dan mahasiswa, dan untuk mengetahui indikator kepuasan dosen dan mahasiswa apa saja yang sudah dilaksanakan oleh program studi Pendidikan Guru Sekolah Dasar. Untuk menganalisis kepuasan dosen dan mahasiswa terhadap kinerja progran studi PGSD dengan metode kualitatif dengan desain deskriptif. Hasil penelitian menunjukan kepuasan dosen dan mahasiswa terhadap layanan prodi PGSD berada pada rentang cukup puas.. Secara umum mahasiswa merasa cukup puas dengan layanan prodi PGSD. Mahasiswa merasa cukup puas pada aspek tangible, reliability, assurance, dan empathy. Kinerja program studi di tanggapi sangat puas oleh dosen dan mahasiswa. Secara umum dosen dan mahasiswa sudah merasa cukup puas terhadap layanan kinerja prodi PGSD tetapi masih terdapat beberapa indikator yang masih memerlukan perhatian prodi PGSD terutama pada aspek tangible, reliability, assurance, dan empathy.
\end{abstract}

Kata Kunci: kinerja program studi; dosen; mahasiswa.

ANALYSIS OF SATISFACTION OF LECTURERS AND STUDENTS ON THE PERFORMANCE OF ELEMENTARY
TEACHER EDUCATION STUDY PROGRAMS, UNIVERSITY OF PAKUAN. Abstract. The quality of educational institutions is strongly influenced by input from various factors that influence it, including
leadership policy factors, facilities supporting the teaching and learning process. The performance of study programs is one of the most important benchmarks of the success of education in a tertiary institution because it will determine the high or low quality of education in tertiary institutions. Lecturers and students often complain about the policies implemented by study programs, especially about the facilities and facilities in the classroom that are not good so that the learning process becomes less conducive. The impact of the problem about dissatisfaction on the performance of the study program is shown by its uncomfortable learning behavior. The purpose of this study is to find out how the study program performance is assessed by lecturers and students, and to find out what indicators of lecturer and student satisfaction have been carried out by Elementary Teacher Education (PGSD) Study Programs. To analyze the satisfaction of lecturers and students on the performance of PGSD Study Programs with qualitative methods with descriptive designs. The results showed that lecturers and students' satisfaction with PGSD Study Programs services was in the quite satisfied range. In general, students felt quite satisfied with PGSD Study Programs services. Students feel quite satisfied with tangible aspects, reliability, assurance, and empathy. The study program performance was responded to very satisfied by lecturers and students. In general, lecturers and students are quite satisfied with the service performance of PGSD Study Programs, but there are still some indicators that still require the attention of PGSD Study Programs, especially in the tangible, reliability, assurance, and empathy aspects.

Keywords: Study Program Performance, Lecturers, Students.

\section{PENDAHULUAN}

Pendidikan adalah faktor yang paling penting dan prioritas utama yang membutuh-kan perhatian serius dari semua pihak, karena pendidikan adalah penentu kemajuan bangsa di masa depan [1]. Tujuan dan cita-cita nasional, untuk kehidupan intelektual bangsa terkandung dalam UUD 1945. Pemerintah bersama masyarakat terus mencari pengembangan pendidikan demi terwujudnya bangsa yang mandiri, unggul dan siap menghadapi dunia globalisasi [2].

Kinerja merupakan hasil atau tingkat keberhasilan seseorang secara keseluruhan selama periode tertentu di dalam melaksanakan tugas dibanding dengan berbagai kemungkinan, seperti standar hasil kerja, target atau sasaran atau kriteria yang telah ditentukan terlebih dahulu dan telah disepakati bersama.

Prawirosentono [3] mengartikan kinerja adalah hasil kerja yang dapat dicapai oleh seseorang atau sekelompok orang dalam suatu organisasi, sesuai dengan wewenang dan tanggung jawab masing-masing, dalam rangka upaya mencapai tujuan organisasi bersangkutan secara legal ,tidak melanggar hukum dan sesuai dengan moral maupun etika. 
Penulis mengartikan kinerja adalah hasil kerja yang dicapai oleh seseorang, sesuai dengan wewenang dan tanggung jawab masing-masing dalam rangka mencapai tujuan pendidikan secara legal, tidak melanggar hukum dan sesuai dengan norma atau etika.

Keberhasilan suatu kinerja individu dipengaruhi banyak faktor, baik faktor internal maupun eksternal. Lowr dalam Natapriatna [4] yang memberikan gambaran lima faktor yang mempengaruhi kinerja individu sebagai berikut: 1) harga diri. (self esteem), 2) pengalaman masa lampau (past experience), 3) situasi aktual (actual situation), 4) kepribadian individu (personality), 5) hubungan dengan yang lain (communications from other).

Subekti dikutip dari Gibson [5] menyatakan bahwa ada tiga faktor yang berpengaruh terhadap kinerja seseorang antara lain: 1) Faktor individu: kemampuan, keterampilan, latar belakang keluarga, pengalaman tingkat sosial dan demogarfi seseorang. 2) Faktor psikologis: persepsi, peran, sikap, kepribadian, motivasi, dan kepuasan kerja. 3) Faktor organisasi: struktur organisasi, desain pekerjaan, kepemimpinan, sistem penghargaan (reward system). Dosen bekerja dengan produktif atau tidak tergantung pada motivasi, kepuasan kerja, tingkat stress, kondisi phisik pekerjaan, sistem kompensasi, desain pekerjaan, dan aspekaspek ekonomis

Dapat ditentukan bahwa kinerja dosen dapat dipengaruhi oleh lima faktor yang dapat dijelaskan sebagai berikut: 1) Harga diri (self esteem), sering menjadi motivasi dosen dalam mencapai sukses di program studi. 2) Pengalaman masa lampau (past experience), sering menjadi tolok ukur seorang dosen dalam melaksanakan tugasnya. 3) Situasi aktual (actual situation) yaitu kondisi di sebuah program studi sering mempengaruhi kebijakan dan kinerja dosen. 4) Kepribadian individu (personality). 5) Hubungan dengan yang lain (communications from other).

Madgopes dalam Natapriatna [4] mengemukakan tujuh indikator kinerja, yaitu: 1) produktivitas, 2) kualitas kerja, 3) inisiatif, 4) kerja tim, 5) pemecahan masalah, 6) tekanan, dan 7) motivasi.

Berdasarkan pendapat tersebut di atas dijelaskan bahwa kinerja dosen dapat diukur dari: 1) Produktivitas yang dihasilkan oleh dosen selama bertugas pada suatu program studi dari waktu ke waktu. 2) Kualitas kerja dosen dalam melaksanakan tugas dan kewajibannya selama bertugas pada program studi tertentu. 3) Banyaknya inisiatif dosen dalam mencari strategi untuk merealisasikan program kerja yang dicanangkan oleh program studi tertentu. 4) Kerja sama dengan dosen, karyawan dan masyarakat dalam merencanakan dan melaksanakan tujuan program studi. 5) Keberhasilan dosen dalam setiap kegiatan program studi. 6) Kemampuan dosen dalam mengatasi tekanan dan intervensi dari pihak luar dan atasan, 7) Kemampuan dosen dalam membangkitkan dan mengelola motivasi yang ada dalam dirinya dan lingkungannnya.

Dessler [6] menyebutkan enam cara yang dapat dilakukan untuk melakukan penilaian terhadap kinerja seseorang (dosen), yaitu: 1) penilaian dilakukan oleh ketua progaram studi (pimpinan) terdekat, 2) penilaian dengan menggunakan penilaian teman kerja, 3) penilaian dilakukan oleh komisi penilai (BPM), 4) penilaian diri yang dilakukan oleh yang dinilai, 5) penilaian dilakukan oleh mahasiswa, dan 6) penilaian melalui umpan balik. Dalam penelitian ini penilaian kinerja dosen dilakukan oleh dosen itu sendiri.

Budaya organisasi dapat diidentifikasikan dari setiap lapisan budaya organisasi yang terbagi dua yaitu lapisan yang dapat diamati dan lapisan yang tersembunyi atau lapisan yang tidak dapat diamati [7]. Marwansyah dan Mukaram [8] mengemukakan bahwa penilaian pimpinan organisasi dapat mengetahui kinerja pegawainya dipandang dari tujuan umum sistem penilaian unjuk kerja adalah:

1. Untuk meningkatkan unjuk kerja karyawan dengan cara membantu mereka agar dapat menyadari dan menggunakan seluruh potensi mereka dalam mewujudkan tujuan-tujuan organisasi

2. Untuk memberikan informasi kepada karyawan dan manajer sebagai dasar untuk mengambil keputusan yang berkaitan dengan pekerjaan.

Disamping itu, untuk mengadakan pengukuran terhadap kinerja diperlukan pengkajian khusus tentang kemampuan dan komunikasi.

Kedudukan seorang dosen sangat penting dalam mempengaruhi pelaksanaan pembelajaran mahasiswanya, tidak mengherankan apabila semua pihak baik dari pemerintah, orang tua mahasiswa serta lainnya sangat memperhatikan terhadap mutu pendidikan yang harus mengarah pada kemampuan seorang dosen.

Berdasarkan Pemaparan di atas dapat disintesiskan bahwa kinerja dosen adalah tingkat pencapaian hasil atau pelaksanaan tugas seorang dosen dalam melaksanakan tugas dan tanggung jawabnya sebagai tenaga fungsional akedemik pada suatu program studi.

Kepuasan adalah suatu keadaan yang dirasakan konsumen setelah dia mengalami suatu kinerja (atau hasil) yang telah memenuhi berbagai harapannya. Menurut Oliver dikutip oleh Irine [9], kepuasan adalah tingkah perasaan seseorang (pelanggan) setelah membandingkan antara kinerja atau hasil yang dirasakan (pelayanan yang diterima dan dirasakan) dengan yang diharapkannya

Pada dasarnya harapan mahasiswa adalah perkiraan atau keyakinan mahasiswa tentang pelayanan yang diterimanya akan memenuhi harapannya. Sedangkan hasil kinerja akan dipersepsikan oleh mahasiswa. Berdasarkan pemaparan di atas dapat kesamaan pandangan bahwa kepuasan merupakan ungkapan perasaan puas apabila menerima kenyataan/pengalaman pelayanan memenuhi harapan mahasiswa.

Kepuasan dosen dan mahasiswa terhadap kualitas pelayanan atau pembelajaran merupakan persepsi seseorang terhadap sesuatu yang telah memenuhi harapannya. Margono [10] memaparkan tentang kepuasan dosen dan mahasiswa terhadap pembelajaran yang dapat dilihat dari 5 dimensi kepuasan yaitu: tangible, reliability, responsiveness, assurance, danempathy.

1. Tangible merupakan dimensi fisik. Suatu jasa tidak dapat dicium, dan tidak dapat diraba, sehingga bukti 
fisik menjadi penting sebagai ukuran terhadap pelayanan.

2. Reliability, yaitu dimensi yang mengukur kehandalan dari pendidikan tinggi dalam memberikan pelayanan kepada mahasiswanya.

3. Responsiveness adalah dimensi kualitas pelayanan yang dinamis.

4. Assurance, yaitu dimensi jaminan kualitas yang berhubungan dengan perilaku staf pengajar atau dosen dalam menanamkan rasa percaya dan keyakinan kepada paramahasiswa.

5. Empathy adalah sikap dosen dalam memberikan pelayanan sepenuh hati.

Semakin berkualitas mutu pelayanan, maka semakin tinggi pula pencapaian kepuasan dosen dan mahasiswa. Kepuasan dosen dan mahasiswa merupakan esensial dalam TQM (Total Quality Management), oleh sebab itu sebuah Perguruan Tinggi harus mengidentifikasi kebutuhan para mahasiswa secara cermat dan berusaha memuaskan dengan memandang bahwa mahasiswa sebagai pelanggan utama yang harus dilayani.

Hal di atas sesuai dengan penelitian Pilar dikutip oleh Bancin [11] yang menyimpulkan, bila konsumen yang merasa puas dapat mempengaruhi satu saja teman atau rekannya mengenai kehebatan suatu produk atau jasa yang ditawarkan suatu perusahaan dan akhirnya mendatangkan seorang konsumen atau pelanggan baru, maka nilai konsumen atau pelanggan yang pertama itu menjadi bertambah dua kali lipat. Jika hal ini di analogikan dalam perguruan tinggi bahwa semakin banyak mahasiswa yang masuk ke perguruan tinggi tertentu akan meningkatkan nilai perguruan tinggi itu sendiri, artinya akan memberikan citra baik kepada perguruan tinggi tersebut.

Tjiptono mengutip Kurniawati [12]. Konsumen dalam hal ini adalah mahasiswa yang berada di dalam perguruan tinggi, sedangkan perusahaan itu sendiri adalah perguruan tinggi yakni Universitas Pakuan khususnya Fakultas Keguruan dan Ilmu Pendidikan (FKIP) Program Studi Pendidikan Guru Sekolah Dasar. Dari uraian-uraian di atas mengindikasikan bahwa dengan adanya peningkatan kinerja dosen maka dapat meningkatkan kepuasan dosen dan mahasiswa.

Menurut Bancin [11] mengungkapkan bahwa kinerja penerimaan langsung yang diterima mahasiswa salah satunya adalah kinerja dari dosen itu sendiri. Maka kinerja harus sesuai dengan harapan costumer yang berarti ketepatan waktu, pelayanan yang sama untuk semua pelanggan tanpa kesalahan, sikap yang simpatik, dan dengan akurasi tinggi.

Bersadarkan hal tersebut penulis menyatakan bahwa bahwa kesan buruk dab baik akan membuat mahasiswa menceritakan kepada orang lain. Kesan baik inilah yang akan berdampak kepada perguruan tinggi.

\section{METODE PENELITIAN}

Pendekatan penelitian yang digunakan dalam penelitian ini adalah dengan menggunakan pendekatan kualitatif. Penelitian kualitatif memiliki karakteristik dengan mendeskripsikan suatu keadaan yang sebenarnya, tetapi laporannya bukan sekedar bentuk laporan suatu kejadian tanpa suatu interpretasi ilmiah (Satori [13]). Penelitian ini menggunakan metode kualitatif dengan desain deskriptif, yaitu penelitian yang memberi gambaran secara cermat mengenai individu atau kelompok tertentu tentang keadaan dan gejala yang terjadi (Koentjaraningrat [14]). Penelitian kualitatif deskriptif merupakan penelitian yang mendeskripsikan suatu permasalahan berupa kata-kata tertulis/lisan dari orang-orang atau perilaku yang dapat diamati.

Pendapat ini didukung oleh Moleong [15] yang menyatakan bahwa penelitian kualitatif deskriptif adalah penelitian yang bermaksud untuk memahami fenomena tentang apa yang dialami oleh subjek penelitian misalnya perilaku, persepsi, motivasi, tindakan, dll., secara holistik, dan dengan cara deskripsi dalam bentuk kata-kata dan bahasa, pada suatu konteks khusus yang alamiah dan dengan memanfaatkan berbagai metode alamiah.

Penelitian ini bertujuan untuk memperoleh gambaran apa adanya tentang bagaimana kinerja dosen pada kepuasan dosen dan mahasiswa. Data yang diperoleh dari penelitian ini merupakan hasil analisis dokumen, observasi, wawancara, dan quesioner dimana hal ini sesuai dengan pendapat Syaodih [16]. Penelitian ini dilaksanakan di Program Studi Pendidikan Guru Sekolah Dasar Fakultas Keguruan dan Ilmu Pendidikan Universitas Pakuan.

Jenis data yang digunakan dalam penelitian ini berbentuk narasi, uraian, penjelasan, dan pengisian angket dari informan baik lisan maupun tulisan yang dideskripsikan dalam bentuk catatan lapangan, angket, dan dokumentasi.

\section{HASIL DAN PEMBAHASAN}

Berdasarkan angket yang dibagikan kepada mahasiswa, diperoleh hasil pengukuran tingkat kepuasan sebagai berikut :

Tabel 1. Dimensi kepuasan Dosen dan Mahasiswa terhadap Kinerja Prodi PGSD

\begin{tabular}{|c|c|c|c|c|c|}
\hline Kepuasan & Tangible & Reliability & Responsiveness & Assurance & Empathy \\
\hline$\%$ & 78,94 & 76,13 & 80,18 & 79,64 & 77,24 \\
\hline
\end{tabular}

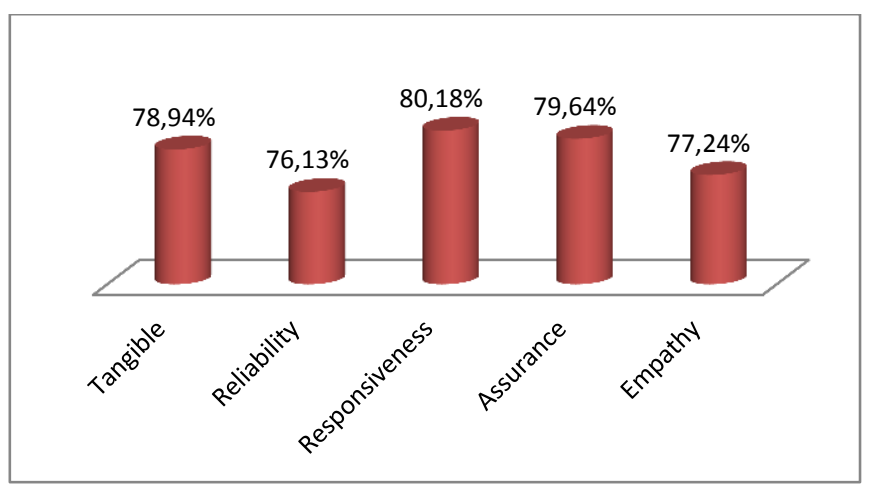

Gambar 1. Kepuasan Dosen dan Mahasiswa 
Penelitian ini membahas tentang kepuasan dosen dan mahasiswa terhadap prodi PGSD, dimana pada hasil penelitian yang diperoleh secara umum terlihat bahwa hampir dari semua aspek mahasiswa merasa puas.

Kepuasan dosen dan mahasiswa terhadap kualitas pelayanan merupakan persepsi seseorang terhadap sesuatu yang telah memenuhi harapannya. memaparkan tentang kepuasan dosen dan mahasiswa terhadap pelayanan prodi yang dapat dilihat dari 5 dimensi kepuasan yaitu: tangible, reliability, responsiveness, assurance, dan empathy.

Kelima dimensi tersebut menggambarkan kualitas kepuasan dari dosen dan mahasiswa terhadap kinerja Program Studi PGSD. Terlihat dari gambar 1. Bahwa kolektif Dosen dan mahasiswa indek kepuasan terhadap kinerja program studi masih relatif sedang. Rata2 indek kepuasan berada di zona kepuasan cukup dan sedang. Hanya dari dimensi responsiveness yang tinggi. Ini memperlihatkan bahwa kinerja Program studi menurut penilaian kelima dimensi ini masih sedang.

Indek kepuasan dosen dan mahasiswa menurut dimensi kualitas kinerja, jika ditinjau secara keseluruhan, indek kinerja berbagai dimensi di Program Studi berada di bawah $80 \%$ kecuali indek responsiveness yang mencapai $80 \%$. Hal tersebut menunjukan bahwa dosen dan mahasiswa Program Studi PGSD cukup puas dengan kinerja yang dilakukan lembaga Program Studi PGSD.

Dikarenakan hanya responsiveness yang indeksnya sudah tinggi. Untuk itu Program Studi diharapkan perlu melakukan peningkatan kinerja pada dimensi-dimensi tangible, reliability, assurance, dan empathy. Hal ini perlu dilakukan untuk meningkatkan kepuasan dosen dan mahasiswa dalam menilai kinerja Program Studi.

Untuk dimensi Tangible program studi perlu meningkatkan kemampuan untuk memberi fasilitas fisik dan perlengkapan perkuliahan yang memadai proses belajar mengajar menyangkut sarana umum, misalnya: ketersediaan sarana prasarana. Mahasiswa dan dosen akan menilai suatu kualitas pembelajaran dari segala sarana dan fasilitas yang ada.

Untuk dimensi Reliability, program studi perlu meningkatkan kemampuan untuk memberikan pelayanan kepada dosen dan mahasiswanya. Ada dua aspek dari dimensi ini, yaitu a) memberikan peningkatan kemampuan dosen dalam memberikan metode pembelajaran seperti yang dijanjikan dan, b) seberapa jauh dosen memberikan pembelajaran secara akurat. Berarti Program studi harus lebih efektif dalam meningkatkan sumber daya manusia dari dosen tersebut dan harus mengontrol proses kinerja dosennya.

Untuk dimensi assurance, program studi perlu meningkatkan kemampuan untuk kompetensi, pengetahuan, keterampilan, kesopanan. Terdapat empat aspek dari dimensi assurance, yaitu keramahan, kornpetensi, kredibilitas, dan keamanan.

Untuk dimensi empathy adalah program studi perlu meningkatkan kemampuan untuk memberikan pelayanan sepenuh hati, seperti perhatian secara pribadi serta pemahaman bahwa setiap mahasiswa dan dosen memiliki kemampuan dan kebutuhan yang berbeda.

\section{SIMPULAN}

Kepuasan dosen dan mahasiswa terhadap layanan prodi PGSD berada pada rentang cukup puas.. Secara umum mahasiswa merasa cukup puas dengan layanan prodi PGSD. Mahasiswa merasa cukup puas pada aspek tangible, reliability, assurance, dan empathy. Kinerja program studi di tanggapi sangat puas oleh dosen dan mahasiswa.

Secara umum dosen dan mahasiswa sudah merasa cukup puas terhadap layanan kinerja prodi PGSD tetapi masih terdapat beberapa indikator yang masih memerlukan perhatian prodi PGSD terutama pada aspek tangible, reliability, assurance, dan empathy

\section{REFERENSI}

[1] Y. Suchyadi and Nurjanah, 2018. Relationship between Principal Supervision in Increasing the Job Satisfaction of Private Junior High School Teachers in East Bogor District," J. Humanit. Soc. Stud., vol. 02, no. 01, pp. 26-29.

[2] Y. Suchyadi, 2017. Relationship between Work Motivation and Organizational Culture in Enhancing Professional Attitudes of Pakuan University Lecturers, J. Humanit. Soc. Stud., vol. 01, no. 01, pp. 41-45, 2017.

[3] Prawirosentono, Suryadi, 1999, Kebijakan Kinerja Karyawan, Yogyakarta: BPFE

[4] Natapriatna, Sulaiman.2001. Kinerja Kepala sekolah: Studi Korelasi antara Pengetahuan tentang Manajemen Sekolah dan Sikap Terhadap Jabatan dengan Kinerja Kepala SD di Kotamadya Depok. Jakarta: Tesis IKIP Jakarta

[5] Subekti. Heru 2008. Indikator Kinerja. Jakarta: Ghalia Indonesia

[6] Dessler, Gary, 1998. Manajemen Sumber Daya Manusia, Jakarta; PT Prenhallindo.

[7] R. Pertiwi and Y. Suchyadi, Implementasi Program Pendidikan Karakter Di Sekolah Dasar Negeri Lawanggintung 01 Kota Bogor," J. Pendidik. Pengajaran Guru Sekol. Dasar (JPPGuseda ), vol. 02, pp. 41-46, 2019.

[8] Marwansyah \& Mukaram. 2000, Manajemen Sumber Daya Manusia, Bandung, Politeknik Bandung Press.

[9] Irine, Diana,. 2009. Manajemen Pemasaran Usaha Kesehatan. Yogyakarta: Nuha Medika.

[10] Margono, Gaguk. 2005. Validitas Konstruk Instrumen Pengukur Tingkat Kepuasan dosen dan mahasiswa sebagai Pelanggan Internal. Jurnal PTM. Vol.5.No.1918

[11] Bancin, Aswin. 2010. Pengaruh kualitas akademik terhadap kepuasan mahasiswa Universitas Muhammadiyah Sumatera Utara". Tesis: Program Pascasarjana Universitas Negeri Medan.Medan. 
[12] Tjiptono, Fandy. 2000. Perspektif Manajemen dan Pemasaran kontemporer. Yogyakarta : ANDI.

[13] Satori, Djam'an dan Komariah, Aan.. 2009. Metodologi Penelitian Kualitatif. Bandung : Alfabeta.

[14] Koentjaraningrat. 1993. Metode-metode Penelitian Masyarakat. (Edisi Ketiga). Jakarta, PT Gramedia Pustaka Utama.

[15] Moleong, Lexy J. 2007. Metodologi Penelitian Kualitatif, Penerbit PT Remaja RosdakaryaOffset, Bandung

[16] Syaodih, Nana Sukmadinata, 2013.Metode Penelitian Pendidikan, Bandung: PT. Remaja Rosdakarya. 